\title{
OPTIMISATION OF DESIGN OF AIR INLETS IN AIR DISTRIBUTION CHANNELS OF A DOUBLE-SKIN TRANSPARENT FAÇADE
}

\author{
Boris BIELEK ${ }^{1 *}$, Daniel SZABÓ ${ }^{1}$, Milan PALKO ${ }^{1}$, Monika RYCHTÁRIKOVÁ ${ }^{2}$
}

\begin{abstract}
This paper reports on an optimization of design of air inlets in naturally ventilated double-skin transparent facades; the design aims at the proper functioning of these facades from the point of view of their aerodynamic and hydrodynamic behaviour. A comparison was made of five different variants of ventilation louvers used in air openings with different shapes, positions and overall geometry. The aerodynamic response of the louvers was determined by $2 D$ simulations using ANSYS software. The hydrodynamic properties were investigated by conducting driven-rain measurements in a large rain chamber at the Slovak University of Technology in Bratislava.
\end{abstract}

\section{Address}

1 STU Bratislava, Faculty of Civil Engineering, Dept. of Building Structures, Radlinského 11, 81005 Bratislava, Slovakia

2 KU Leuven, Faculty of Architecture, A\&T, Hoogstraat 51, 9000 Gent, Belgium

* Corresponding author: boris.bielek@stuba.sk

\section{Key words}

- Double-skin façade,

- Cavity,

- Ventilation louvers,

- Aerodynamic resistance,

- Wind-driven rain.

\section{INTRODUCTION}

The technology of building façades is determined by architectural trends and the development of technology itself, societal requirements and other factors. In present day European architecture, the design of modern wall claddings is driven by climate-specific contexts on the one hand and on the other hand in response to regulatory and social aspects governing the quality of work environments. Ecological, low-energy architecture with automated control systems for environmental, energy, security, transport, communication and information processes is also finding a home in facade technology that uses environmentally-friendly renewable energy sources that are in line with the concept of sustainable development of the European construction industry.

The double-skin transparent façade (DSTF) concept is one of the types of the facade technology of buildings that uses environmentally-clean alternative source of solar energy; although the concept is not completely new, the growing tendency to use these facades in architectural design, especially in Europe, cannot be denied (Poirazis, 2006; Bielek et al., 2002). In addition, double-skin facades, historically speaking, have been used more often in European architecture than in the United States. This is probably due to significantly higher energy prices in Europe and a traditionally higher concern for ecolo- gy and the environment (Vaglio et al., 2010; Directive 2010/31/EU, 2010). Recent building research, which includes different kinds of facade systems and recently operating EU networking actions (COST Action TU1403; COST Action TU1303) has confirmed the importance of modern facade systems in contemporary architecture.

From a technical point of view, development of modern double-skin transparent facades is based on the physical theory of cavities, which allows for a wide range of modifications, e.g., in cavity geometry or in the types of glazing systems used (Bielek et al., 2002). The theory of cavities is based on the quantification of their physical behaviour; this rather complex issue of so-called multi-skin structures has been a point of interest to many authors. A variety of calculation methods related to DSTF behaviour, such as models for the prediction of temperatures or airflows inside a cavity, were developed and introduced at the beginning of the $21^{\text {st }}$ century. It has been shown that underestimating the physical dimensioning of details, components and systems of DSTF as a whole, can lead to major defects with adverse effects on their functioning. This evidence has been confirmed by problems encountered by a number of existing buildings (Todorovic and Maric, 1998; Arons, 2000).

Todorovic and Maric (1998) introduced a calculation model valid for Central European climatic conditions that estimates the air 
temperature and cooling (heating) load per hour in a DSF cavity. A simplified two-dimensional numerical model for the prediction of the energy behaviour of a typical DSF was published by Arons in the year 2000. One year later, a model for the prediction of the thermal transmittance of multiple glazing based on Computational Fluid Dynamics (CFD) was introduced by Gan (2001), and a numerical model for the evaluation of the thermal behaviour of active envelopes was developed and validated in experimental cases by Saelens and Hens (2001), who also integrated it in an energy simulation program. Later, Hensen et al. (2002) used a network approach for calculating the properties of the air inside a double skin façade cavity and integrated it into a building thermal energy model. Saelens (2002) developed a calculation algorithm for 2D multi-skin facades with natural and mechanical ventilation. His theory is valid for single-storey buildings. Gratia and de Herde (2004) published a model for thermal behaviour and heating (cooling) loads depending on the season under the climatic conditions of Belgium and studied the efficiency of natural ventilation in relation to a double-skin facade orientation, wind speed and direction. Grabe (2002) proposed a prediction tool for modelling the temperature's behaviour and flow characteristics in DSF, and Manz (2002) introduced a numerical algorithm for predicting heat transfer by natural convection in cavities of façade elements. Most recent scientific works are based on computational fluid dynamics models, which allow for detailed airflow study in DSTF, as compared to network or other models (Mingotti et al., 2011; Nore et al., 2010; Blanco et al., 2014). In particular, CFD is an interesting method, especially when dealing with very complicated airflows across venetian blinds, air recirculation, or in cases in which the velocity profile is not symmetrical (Grabe, 2002; Manz, 2002; Zeng et al., 2012).

In the literature, special attention has also been given to investigations of the effect of integrated shading devices on cavity properties (temperatures, airflow, etc.), which are valid for mechanically-ventilated double-skin glass facades (Parra et al., 2015; Gratia and de Herde, 2004). Manz and Simmler (2003) described a calculation procedure based on a 2D computational fluid dynamic model for a mechanically-ventilated glass double façade with an integrated shading device. Poirazis and Rosenfeld (2003) researched how the temperature in different types of façade panels depends on the heights of the cavities. Gratia and Herde (2004) studied the impact of the orientation of a naturally ventilated double-skin façade in terms of wind direction and observed that the air temperature will rise over the daytime in cases when shading elements are present (in the cavity). Baldinelli (2009) showed that the annual energy behaviour of a double-skin facade is significantly improved in cases when blinds are installed in the cavity of a south facade of a building.

Several other authors have focused on strategies for improving the thermal performance of a DSF, including shading devices (Guardo et al., 2009) and on coping with large numbers of meshes in CFD models due to the large amount of Venetian blind slats, which result in long calculation times, e.g., Zeng et al (2012) proposed a CFD method that uses a porous media model.

Recent research has also focused on an assessment of shading devices such as Venetian blinds that are mounted indoors on daylight transmission and interior illuminance (Tzempelikos, 2008) and their impact on thermal behaviour (Manz and Menti, 2012; Manz et al., 2004). Saelens et al. (2005) showed that controlling the airflow rate and recovering the air returning from a DSF can significantly improve the heating and cooling demands of multi-skin facades in Belgian climatic conditions. Ding et al. (2005) determined that the addition of a ventilation chimney above a DSF also assures natural ventilation without the presence of wind. The importance of modelling a correct inlet temperature (naturally and mechanically ventilat- ed DSFs) has especially been stressed in cases where the air flowing through a cavity is to be reused (Cole et al., 1998). Authors have pointed out that the assumption of an inlet temperature equal to an interior or exterior air temperature is usually not valid.

The efficiency of the sizes of the inlet and outlet of double-skin facades was discussed in (Saelens et al., 2003). In the research of Gelesz and Reith (2011), the recommended values were given as a fraction of a $1 \mathrm{~m}^{2}$ equivalent leak area at $4 \mathrm{~Pa}$ for a façade element with a width of $2.7 \mathrm{~m}$. Interestingly, in cases involving the application of Venetian blinds, openings twice as large were necessary in comparison with a white shading system.

The shape of a building to induce airflow buoyancy in general was investigated by Cole et al. (1998) who pointed out that a precise orientation of a building facade to the wind is not critical and that even in cases when walls are angled up to $30^{\circ}$ to the wind, enough pressure that is necessary for natural cooling is created.

In terms of establishing an efficient general concept of DSTF, the integration of several aspects related to building physics is necessary. Information on the behaviour of a double-skin facade subject to a fire can be found in the works of Chow et al. $(2007 ; 2012)$ and Ni et al. (2012). Chow and Hung (2006) concluded that wider cavities might be safer since the likelihood that inner glass panels would break is smaller. They also recommended that the application of tempered glass is safer.

The acoustic properties of multi-layer structures have also been examined by many authors (Hongisto, 2006; Roozen et al., 2015; Muellner et al., 2008; Dijckmans and Vermeir, 2013). However, not much information can be found about experiments specifically performed for double-skin transparent facades. A well-known publication is based on the research study of Blasco $(2004 ; 2012)$ who by means of double wall sound propagation theory, showed three possible ways to predict the sound insulation of prediction of DSTF's. A very recent and extensive study based on a number of in situ measurements, laboratory experiments and boundary element simulations, was conducted by Urban et al. in 2016. This research is particularly important as it uses a laser-doppler vibrometry approach, which allows for the investigation of low-frequency components in sound insulation, the so-called bass sound. It also tackles highly complex sound insulation issues and shows both the sound insulation of a façade together with the impact of a DSTF on sound insulation between offices; it also deals with speech privacy issues (Urban et al., 2016).

A commission of the European Council (Blomsterberg, 2007) prepared a document summarizing some guiding principles for the application of a double-skin façade in 2007.

The present paper is a contribution to the theory of the design of air inlets on the distribution channels of double-skin transparent facades with corridor types of cavities as related to their functional aerodynamics and hydrodynamics. The proposal is based on a summary of the knowledge gained from the authors' experiments and simulations.

\section{THEORY AND DESIGN PRINCIPLES}

For the proper functioning of naturally ventilated façade systems, it is necessary to pay special attention to suitable designs for air openings. What is crucial are local aerodynamic resistances at the air inlets and outlets from the distribution channels of the cavity; the inlet louvers must be designed in such a way so as to achieve an overall aerodynamic resistance that is lower than the strength of the convective air buoyancy in the cavity under still air (i.e. without wind) conditions. Inlet louvers, together with protective screens against birds and insects, represent a rain barrier to the inlet openings of distribution 
channels of a cavity burdened by the intensity of wind-driven rain.

The design of a double-skin transparent façade thus requires a careful consideration of its aerodynamic and hydrodynamic properties.

\subsection{Aerodynamic behaviour of a double-skin transparent facade}

One of the fundamental presumptions for the proper operation of any double-skin transparent façade is its functional aerodynamic behaviour, which is expressed by its total aerodynamic resistance consisting of the aerodynamic resistances of friction and local resistances along the airflow trajectory through the cavity, i.e. securing the movement of air in the cavity under every possible climatic condition. A critical state occurs under still air, when the air movement in the cavity is only caused by the force of convective air buoyancy.

A double-skin transparent façade can be aerodynamically expressed by its total aerodynamic resistance by equation 1 :

$$
\mathrm{Z}=1+\frac{\bar{\lambda} \cdot(\mathrm{H}+\mathrm{b})}{\mathrm{D}_{\mathrm{h}}}+\sum_{\mathrm{x}=1}^{\mathrm{n}} \xi_{\mathrm{x}}(-)
$$

where $\bar{\lambda}$ is a coefficient of the friction resistance along the height of the trajectory of the movement of the air flow (Figure 1) $\bar{\lambda}=f(\operatorname{Re})$, $\operatorname{Re}(-)$ is Reynolds number, which gives the ratio of inertial forces and viscous forces acting on the flow of liquids and its value determines whether fluid flow is laminar or turbulent; $D_{\mathrm{h}}(\mathrm{m})$ is the aerodynamic diameter of the cavity; $H$ is the effective height of the cavity (m); b is the width of the cavity $(\mathrm{m})$; and $\xi_{\mathrm{x}}$ is an aerodynamic coefficient of the local resistance " $x$ " (-) as explained in Figure 2.

Based on (eq.1), we can conclude that the resistances along the length are directly proportional to the length of the trajectory of the airflow movement in the cavity $H+b$, as indicated in Figure 2, and is inversely proportional to the diameter of the cavity $D_{\mathrm{h}}(\mathrm{m})$. Local resistances are bonded to a specific place of the trajectory of the airflow movement inside the cavity and originate from parts where the velocity or direction of the air flow movement changes (Figure 2). The coefficient of friction resistance $\bar{\lambda}(-)$ and the aerodynamic coefficients of the local resistances $\xi_{2}, \xi_{3}, \xi_{4}, \xi_{5}, \xi_{6}, \xi_{7}, \xi_{8}$ and $\xi_{9}(-)$ are determined in accordance with the theory of aerodynamics given in the illustrations (Figures 3 and 4).

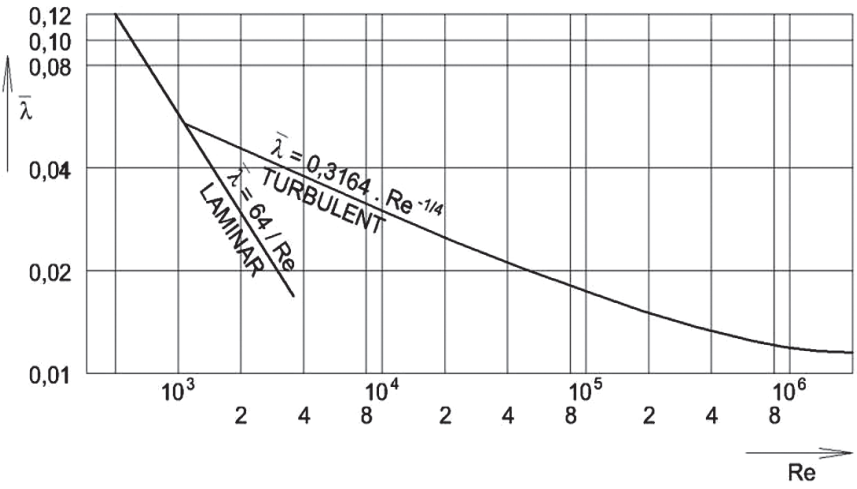

Figure 1. Graphic representation of a coefficient of friction as a function of the cavity height $\bar{\lambda}=f(\mathrm{Re})$
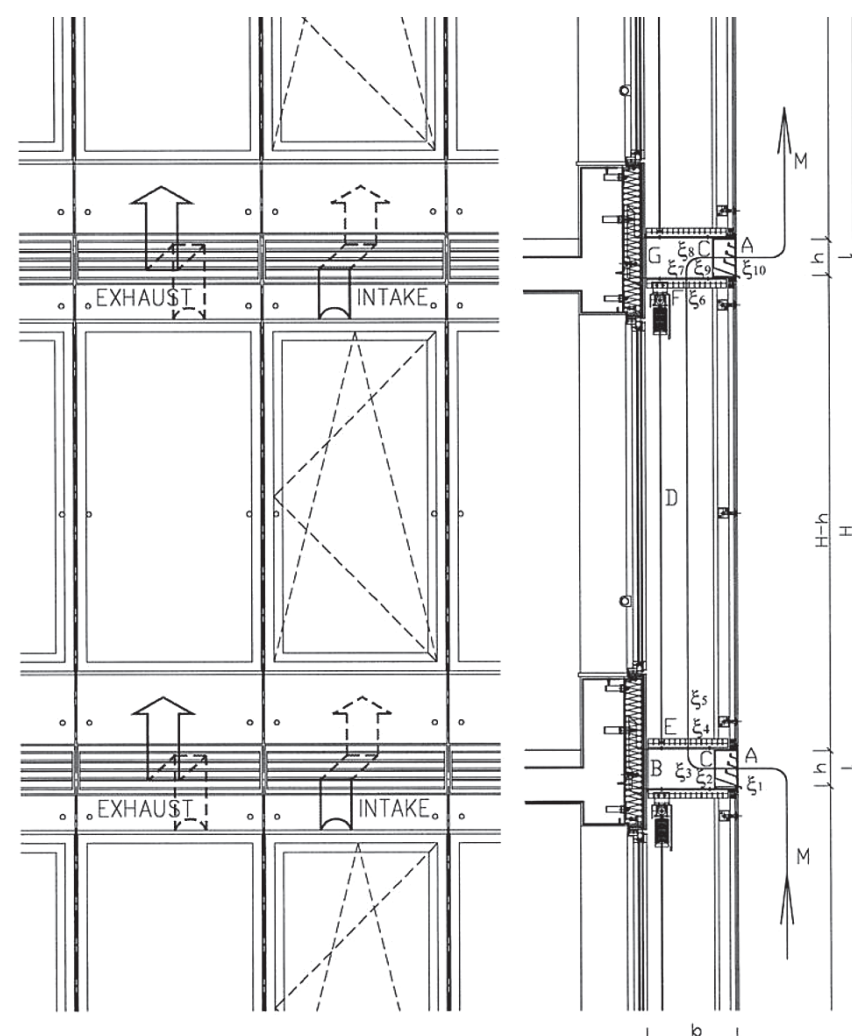

Figure 2. Schematic illustration of the definition and quantification of the aerodynamic resistances of a corridor-type double-skin transparent facade with a circuit open year-round.

Summary of all the symbols used in Figure 2:

A - convective rain barrier or aerodynamic louvers

B - air intake channel

C - protective screen against birds and insects

D - cavity of the climate facade

E - operable removable metal floor grid

F - ceiling grid

G - air exhaust channel

$H(\mathrm{~m})$ - height of segment of cavity

$h(\mathrm{~m})$ - height of openings of air distribution channels

$b(\mathrm{~m})$ - width of cavity

$L(\mathrm{~m})$ - length of segment of cavity

M - air flow trajectory

$\xi_{\mathrm{x}} \quad$ - aerodynamic coefficient of local resistance of airflow, in particular:

$\xi_{1} \quad-$ at inlet on aerodynamic louvers "A"

$\xi_{2} \quad$ - on protective screen "C" at inlet

$\xi_{3}-$ where flow direction changes from inlet channel "B" to the cavity "D"

$\xi_{4} \quad$ - on grille - grid "E" during flow from inlet channel "B" to the cavity "D"

$\xi_{5} \quad$ - upon sudden increase in diameter during movement of airflow from inlet channel " $B$ " to cavity " $D$ "

$\xi_{6} \quad$ - on grid "F" during flow from cavity "D" to outlet channel "G"

$\xi_{7} \quad$ - upon sudden decrease in diameter during movement of airflow from cavity "D" to outlet channel "G"

$\xi_{8} \quad$ - upon change of direction of movement from cavity " $\mathrm{D}$ " to outlet channel " $\mathrm{G}$ "

$\xi_{9} \quad-$ on protective screen "C" at outlet

$\xi_{10} \quad-$ on aerodynamic louvers "A" at outlet 


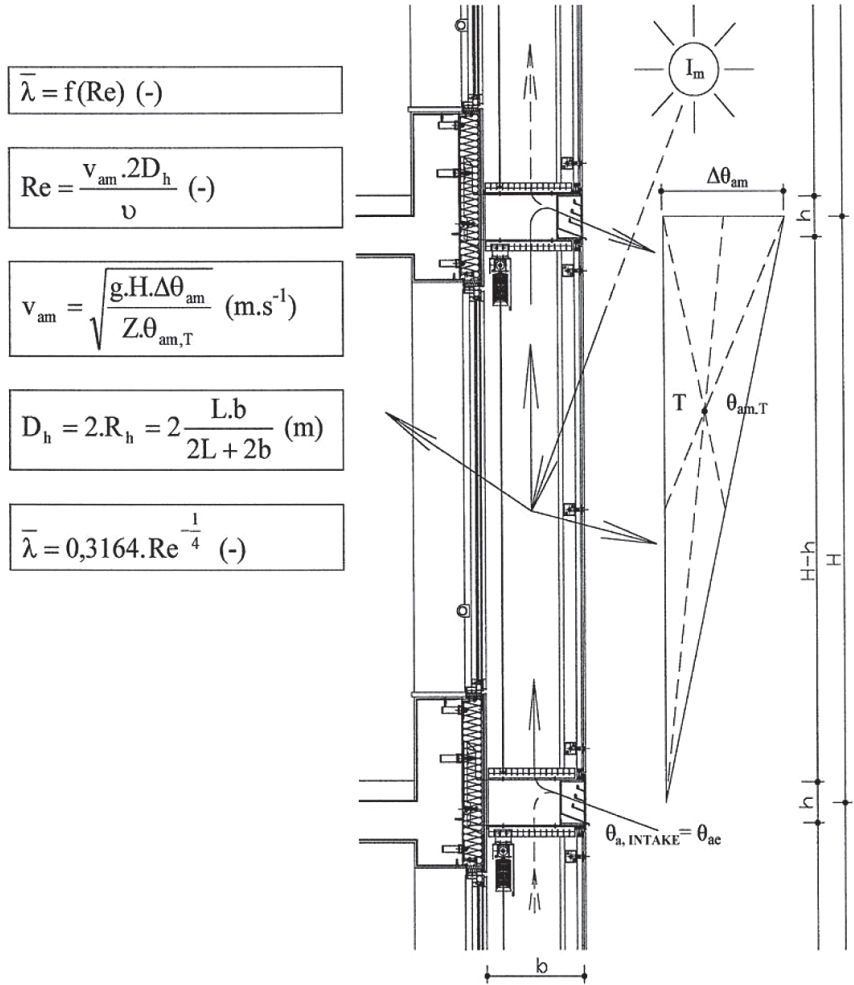

Figure 3. Coefficient of friction resistance along the height of the trajectory of the convective air flow

To achieve the necessary movement of the airflow through the cavity under every climatic condition (also under still air), the overall aerodynamic resistance $Z$ has to be lower than the power of the convective air buoyancy in the cavity. For a double-skin transparent façade with a corridor type of cavity and width $b$ between $0.5<b$ (m) $\leq 1.5$ and a height of the façade segment $H$ equal to the height of a floor height (as indicated in Figure 2), the following equation (eq.2) can be applied:

$$
\max Z=1+\frac{\bar{\lambda} \cdot(H+b)}{D_{h}}+\sum_{x=1}^{n} \xi_{x} \leq 18(-)
$$

In calculating the total aerodynamic resistance of a cavity of a double-skin transparent facade according to equation (eq. 2), two local resistances can be considered as crucial: (1) The local aerodynamic resistance of the air flow at the inlet of the feeding channel with protective screen $\mathrm{A}$, which characterizes the turbulence of the air flow at the inlet to the feeding channel B (Figures 4 and 5), and (2) the local aerodynamic resistance of the air flow at the outlet of the exhaust channel from the cavity with a protective screen A which is responsible for the turbulence of the air flow from the exhaust channel G.

The protective screen at the air inlet and outlet has a role in ensuring the elimination of the penetration of rainwater from the complex effects of wind-driven rain into the cavity. The slats of louvres can, in principle, be designed as classical rain screens or aerodynamic slats. Their local aerodynamic resistances at the inlet of a distribution channel are shown in Figure 5, and the outlet of the distribution channel is shown in Figure 6.

Based on the analysis of the coefficients of the local resistances, it can be concluded that it is not possible to use conventional rain screen louvers on these inlets of DSTF because of the following:

(1) When typical (conventional) rain screen louvers are applied, it is not possible to ensure the optimal ratio to the total area (eq.3):

$$
\frac{\mathrm{a}}{\mathrm{A}} \cdot 100 \cong 80 \%
$$

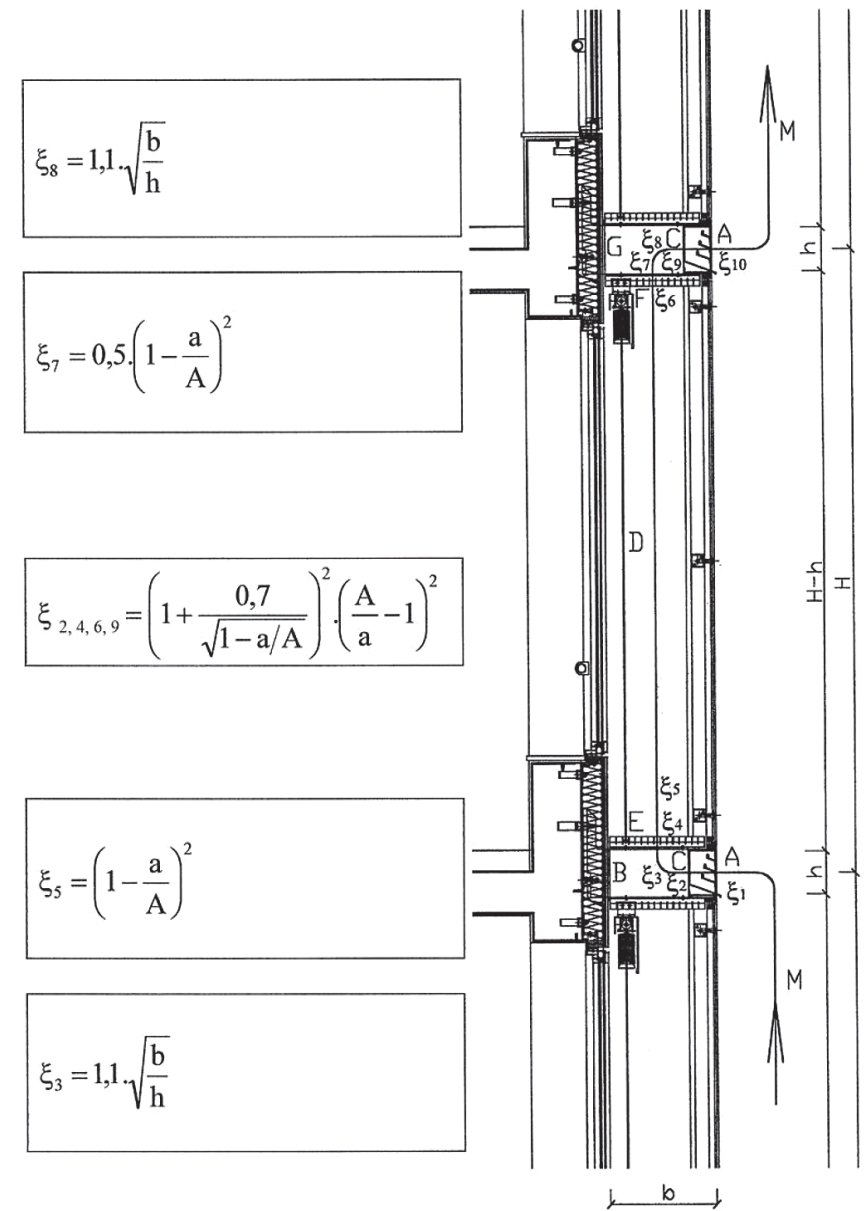

Figure 4. Aerodynamic coefficients of local resistances $\xi_{2}, \xi_{3}, \xi_{4}, \xi_{5}$, $\xi_{6}, \xi_{7}, \xi_{8}, \xi_{9}(-)$ in the trajectory of air flow
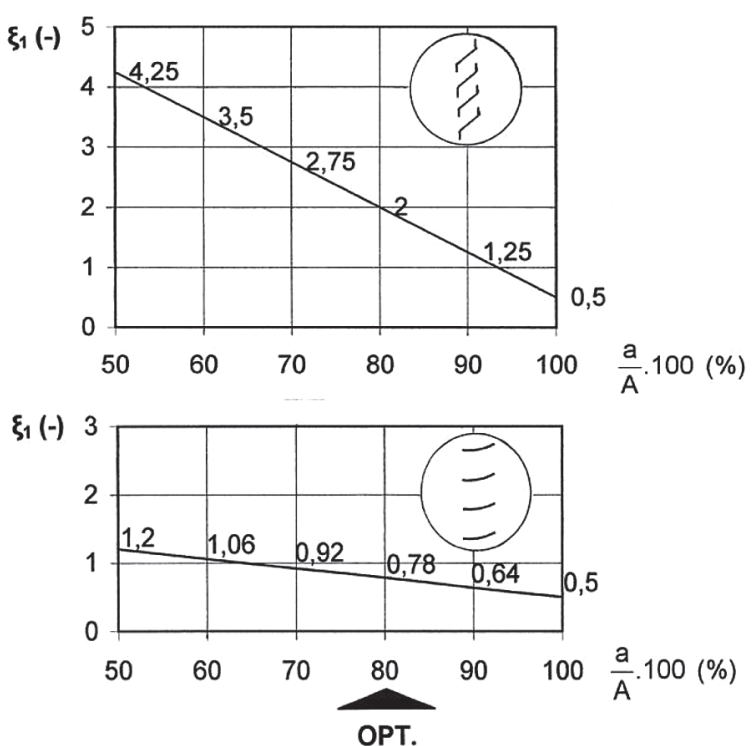

Figure 5. The local aerodynamic resistance of the air flow at the inlet. Upper picture - conventional rain screen louvers, Lower picture - aerodynamic louvers 

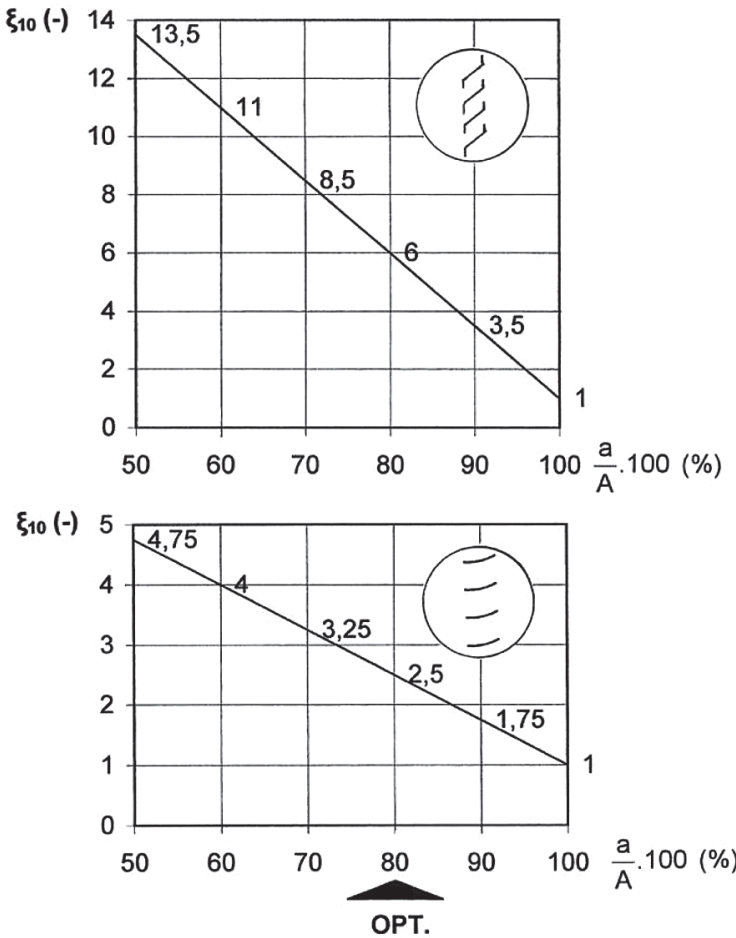

Figure 6. The local aerodynamic resistance of the air flow at the outlet. Upper picture - conventional rain screen louvers, Lower picture - aerodynamic louvers

where " $\mathrm{a}$ " is a net area opening for air movement, and " $\mathrm{A}$ " is the tota area of the air inlets, including the rain screen louvers.

(2) The application of typical rain screen louvers leads to high values of the aerodynamic coefficient of the local resistance at the inlet $(\xi)$, particularly at the outlet $\left(\xi_{10}\right)$ of the distribution channels.

Both facts influence the overall aerodynamic resistance of the cavity of the DSTF on such a large scale that, by their application, it is not possible to ensure the requirement given by eq.4:

$$
\text { opt.Z }=1+\sum \frac{\bar{\lambda} \cdot(H+b)}{D_{h}}+\sum_{x=1}^{10} \xi_{x} \approx 18
$$

at which the convective buoyancy of air is still higher than the overall aerodynamic resistance of the cavity, thus also ensuring the movement of air in the cavity of DSTF in a situation without any wind.

Therefore, the construction of air inlets and outlets should be provided for by the use of aerodynamic louvers with an aerodynamic quantification expressed by the aerodynamic coefficient of local resistance $\xi_{1} \leq 1.0$ and $\xi_{10} \leq 3.0$. This can be calculated and verified, e.g., by means of Computational Fluid Dynamics (CFD) simulation. This has already been previously investigated by some of the authors of this article (Palko, 2015). For the completeness of this paper, an example of the simulation performed in ANSYS is shown in Figure 7.

\subsection{Hydrodynamic behaviour of a double-skin transparent facade}

The hydrodynamic behaviour of the air intake and air exhaust openings of the distribution channels of the cavity is a demanding part of the experimental verification of the physical properties of a DSTF.

One of the most difficult tasks is to design the ventilation louvers with a protective screen against birds and insects. Based on the pri-
B

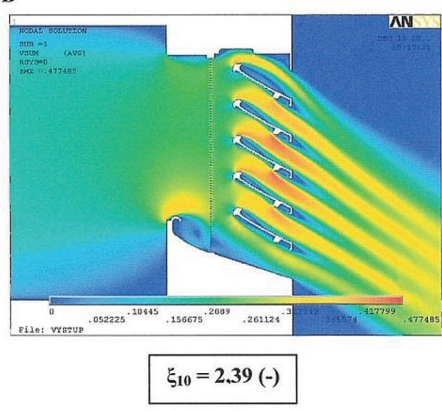

A
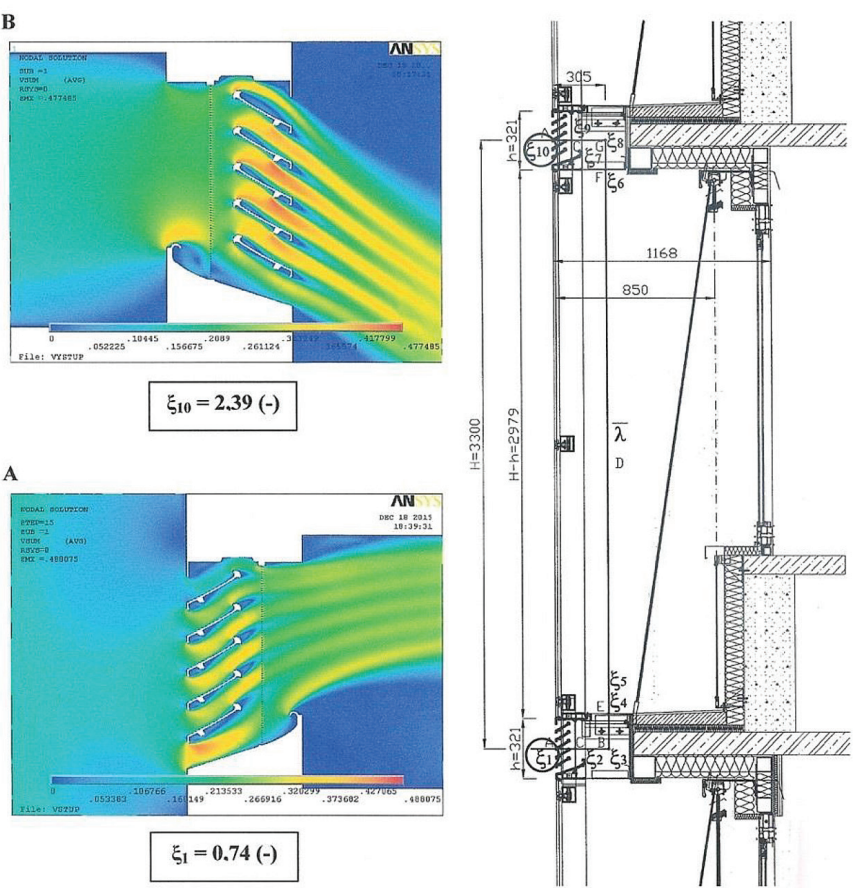

Figure 7. Calculation of the aerodynamic coefficients of local resistance $\xi_{1}$ and $\xi_{10}$ in ANSYS supported by numeric model FLOTRAN CFD. Velocity fields in the area of ventilation louvers and protective screen for intake speed $v=0.2 \mathrm{~m} / \mathrm{s}$. $A$ - at air intake, $B$ - at air exhaust

mary requirements of the airflow, the aerodynamic quantification expressed by the aerodynamic coefficient of the local resistance has to be $\xi_{1} \leq 1.0$ and $\xi_{10} \leq 3.0$. Aerodynamic ventilation louvers, together with the pressure conditions in the cavity, create a rain barrier system for the air intake openings, which are under the pressure of wind-driven rain intensity $r_{\mathrm{v}}(\mathrm{mm} / \mathrm{h}),\left(\mathrm{l} /\left(\mathrm{m}^{2} \cdot \mathrm{h}\right)\right)$. Since wind-driven rain is also characterized by a vector quantity (wind), which consists of the velocity $v(\mathrm{~m} / \mathrm{s})$ and direction $(\mathrm{S}, \mathrm{N}, \mathrm{W}, \mathrm{E})$, the intensity of the wind-driven rain increases with the height (above the ground) too. This is an important aspect when designing facades for high-rise buildings. The rain barrier system (of the air intake openings in the DSTF cavity) that is designed in accordance with the above-mentioned information should have a hydrodynamic behaviour characterized by the impermeability of water to counteract the complex effects of wind-driven rain.

\section{EXPERIMENTS}

The hydrodynamic behaviour of the rain barrier system of the openings of the distribution channels was examined in a laboratory experiment in the Scientific Laboratory of the Building and Construction Physics at the Faculty of Civil Engineering at the Slovak University of Technology in Bratislava.

\subsection{Description of the set-up and elements tested}

The test sample used in the experiments was represented by a spatial element, which consisted of (1) a cavity with air distribution channels (Figure 8) and (2) a flat panel with a removable element with ventilation louvers. Five different variants of the louvers were examined (Figure 9). 

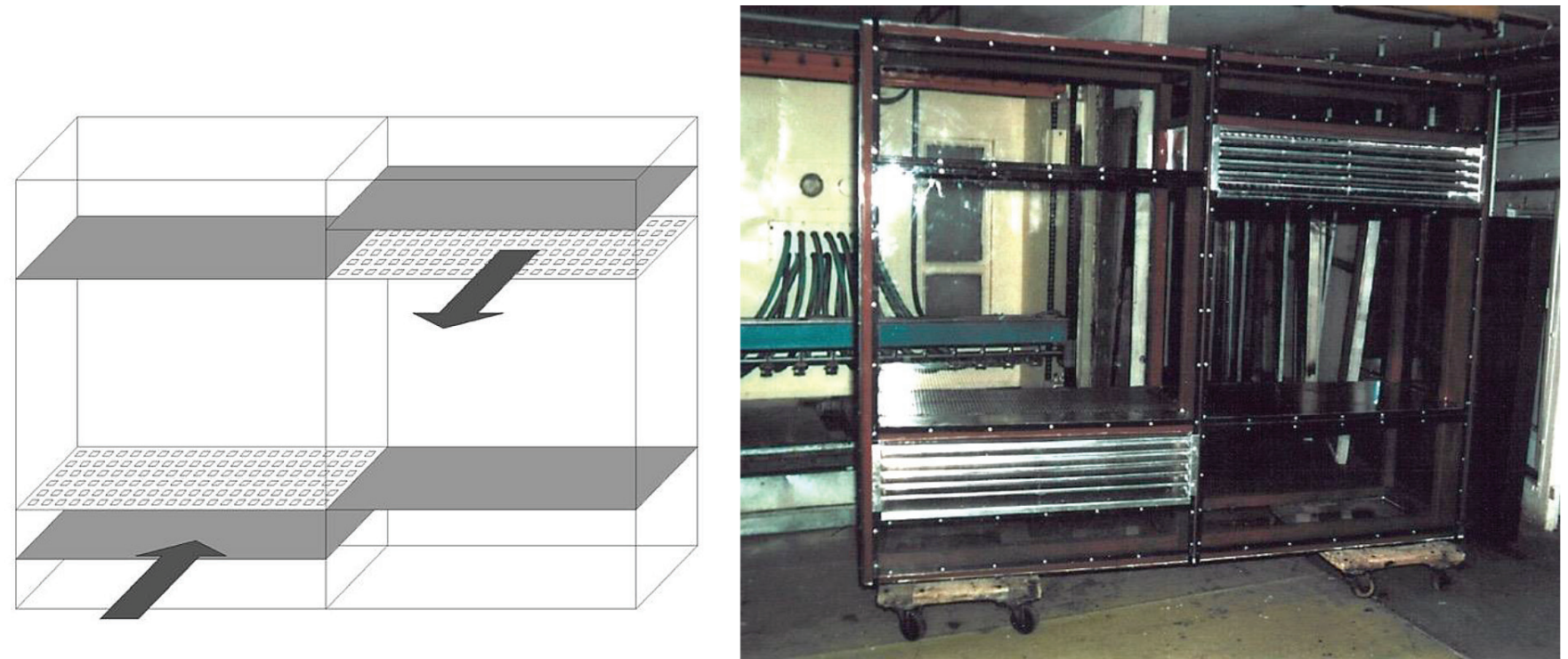

Figure 8. Test sample of the cavity. A schematic representation of the test sample (picture-left). The photo from the laboratory shows the complex spatial test element with ventilation louvers, which was prepared for its insertion into the large rain chamber (picture-right).

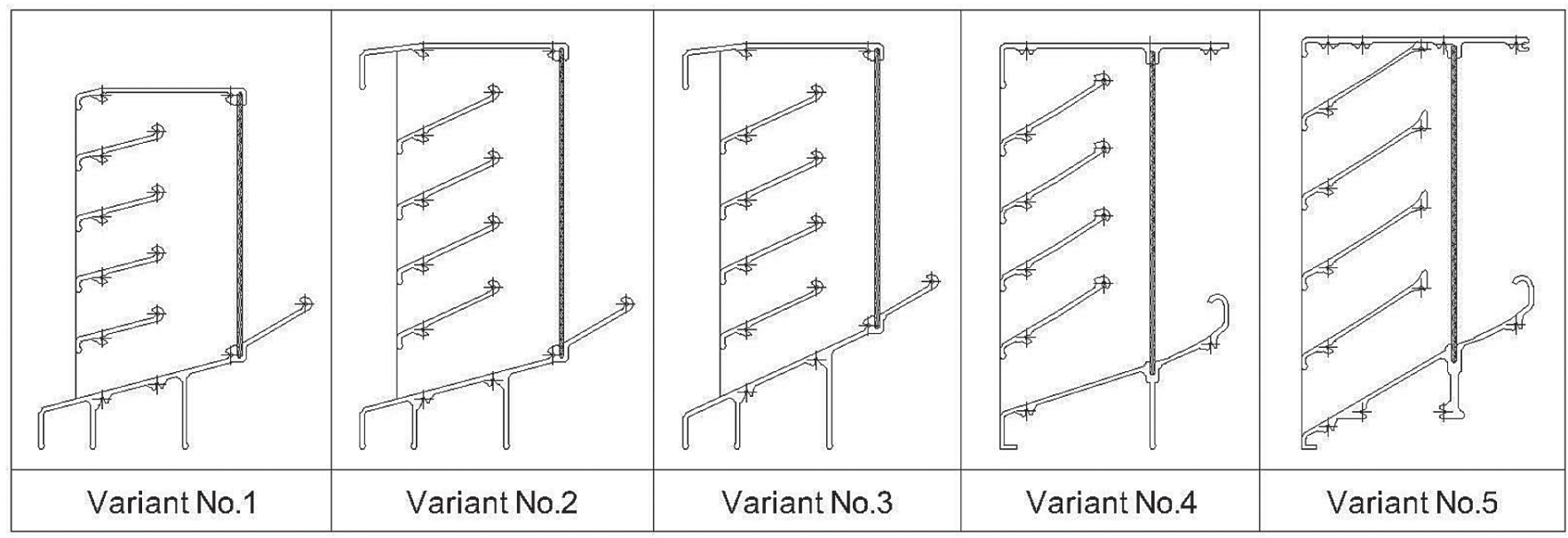

Figure 9. Geometric-construction variants of the experimentally examined ventilation louvers

The cavity with the air distribution channels was $600 \mathrm{~mm}$ wide; its geometry and the direction of the airflow represented the geometrically smallest length of the cavity, as expressed by two $1125 \mathrm{~mm}$ modules with the switched functions of the ventilation louvers (Figure 8).

The test sample with the ventilation louvers (Fig. 8) was inserted into the large rain chamber, which was designed for research on water penetration phenomena through construction details as well as for the elements and systems of building envelopes in general.

The rain chamber consists of four circuits: (1) A circuit of intensity driven rain (with an hourly density of driven rain $r_{\mathrm{v}}=17 \mathrm{l} /\left(\mathrm{m}^{2} . \mathrm{h}\right)$ for buildings up to 10 floors, $r_{v}=18 \mathrm{l} /\left(\mathrm{m}^{2} . \mathrm{h}\right)$ for buildings up to 20 floors and a daily density of driven rain $r_{v}=10 \mathrm{l} /\left(\mathrm{m}^{2} . \mathrm{h}\right)$ with duration of 6 hours). This also simulates the variability of the pressure factor of driven rain, a mobile system of nozzles is shown in Figure 10 - upper pictures A and B. (2) A circuit of the steady-state inflow of water which, thanks to the intensity of driven rain, falls on the analysed spot and moves downwards due to gravity (density of steady-state water influx $\mathrm{Q}=100 \mathrm{l} /(\mathrm{m} . \mathrm{h})$ ) is shown in Figure 11.A. The next part of the rain chamber consists of (3) circuit of so-called gusty wind (with a max velocity of wind $v_{\mathrm{N}}=45 \mathrm{~m} / \mathrm{s}$ and an average velocity between wind gusts $v_{\text {average }}=5.0 \mathrm{~m} / \mathrm{s}$ ). It is displayed in Figure 11.B. The last circuit is the (4) circuit of air pressure differences $15 \leq \Delta \mathrm{p} \leq 700 \mathrm{~Pa}$ for buildings up to 10 floors and $15 \leq \Delta \mathrm{p} \leq 1000 \mathrm{~Pa}$ for buildings up to 20 floors.

The circuits of the wind airflows and air pressure differences are synchronized. The system of nozzles creates water drops (with known sizes and weights), depending on the simulated rain intensity, the synchronization is provided by replaceable splitters (sprays), which are shown in Figure 11.B.

\subsection{Description of the measurement procedure}

First, all four circuits of the rain chamber were calibrated (Figure 10). Then the test sample was mounted in the rain chamber, and the measurements of the air pressure differences and the speed of the equalization of the pressure in the cavity were performed by the "Digima LPU" (SPECIAL INSTRUMENTS, Germany) electronic digital micromanometer. Thanks to its high sensitivity, it was pos- 
A

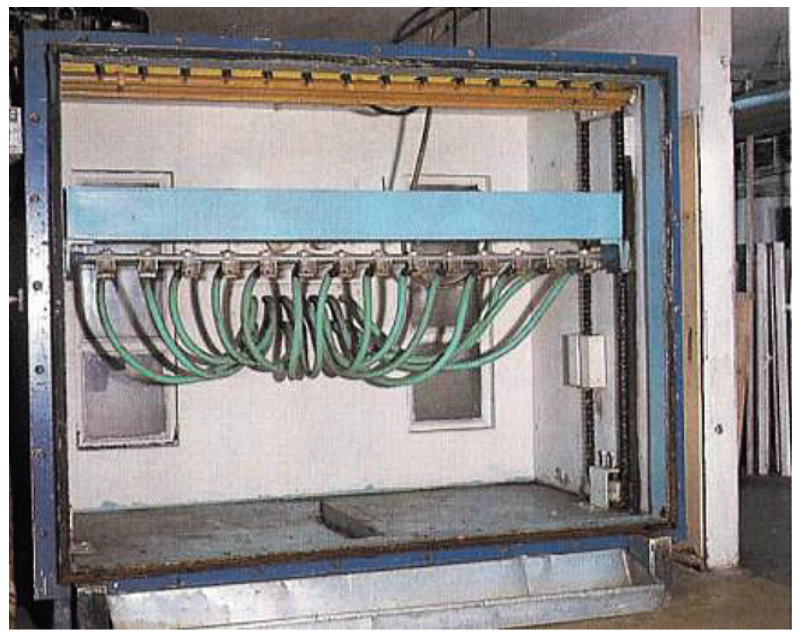

B

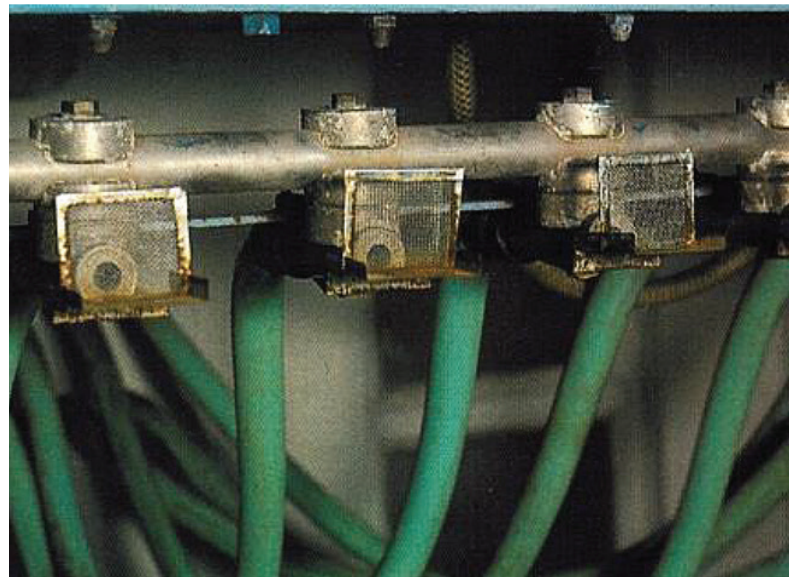

C

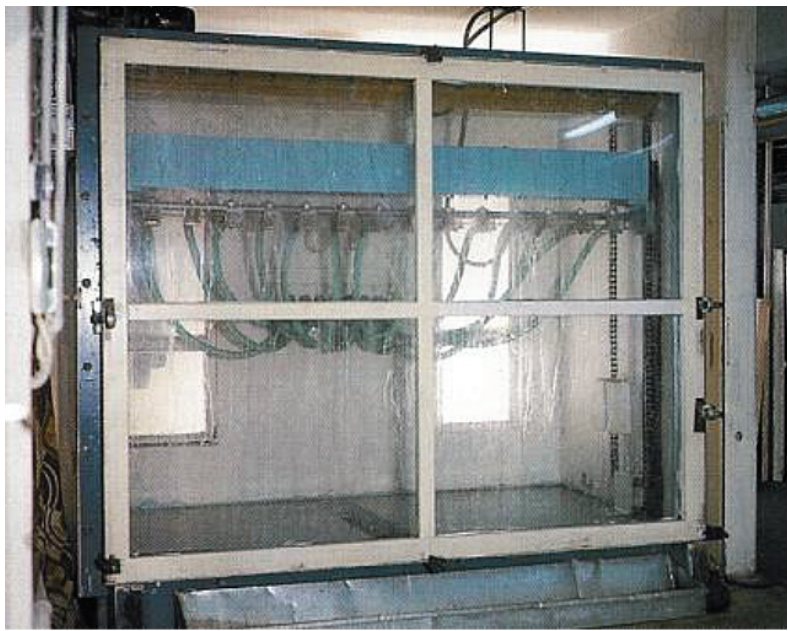

D

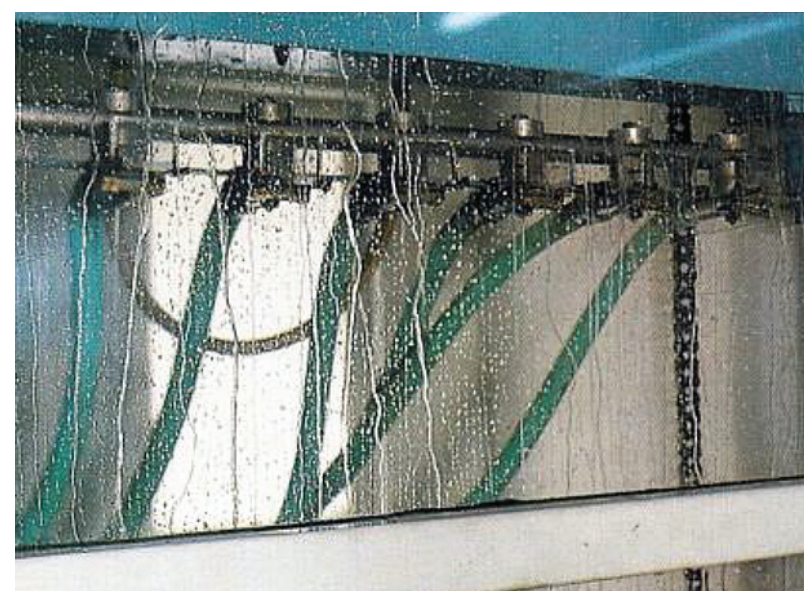

Figure 10. Rain chamber.

$A$ - a view of the rain chamber for the simulation of the complex effects of wind-driven rain. The circuit of the steady-state inflow of water (above), the circuit of the intensity driven rain (in the middle), $B$ - replaceable splitters for synchronization of the rain drops and their intensity. Distribution system of airflows, $C$ - rain chamber during its calibration, $D$ - detailed view on the splitters during the calibration process.

sible to measure pressure differences as fine as single pascals. All the measured data were recorded and saved for post processing. The basic measuring range of the instrument is $200 \mathrm{~Pa}$.

The measurements of the airflow velocity were performed by means of the 55 K10 (DISA ELEKTRONIK, Denmark) measuring system. This system works on the principle of heated fibres with a diameter of $5 \mathrm{~m}$. Thanks to the low thermal inertia of a fibre even very fast changes in the flow rate can be measured. The system also has a high spatial resolution of the air velocity for the given size of the fibre.

The hydrodynamic behaviour of the air intake openings was examined on five (5) different elements of the rain barrier system illustrated in Figure 9. The selected elements consisted of different shapes of the ventilation louvers and a protective screen, as indicated in Figure 9. The dimensions of the louvers are summarized in Table 1 and Figure 11.

\section{RESULTS AND DISCUSSION}

The experiments showed that a critical amount of rain water gets into a cavity due to fragmentation of the raindrops. At higher speeds of airflows during wind gusts $\left(\mathrm{v}_{\mathrm{N}} 15 \mathrm{~m} / \mathrm{s}\right)$ the phenomenon of splintering raindrops was observed. This can be explained by the kinetic energy of water drops on the blades of the ventilation louvers.

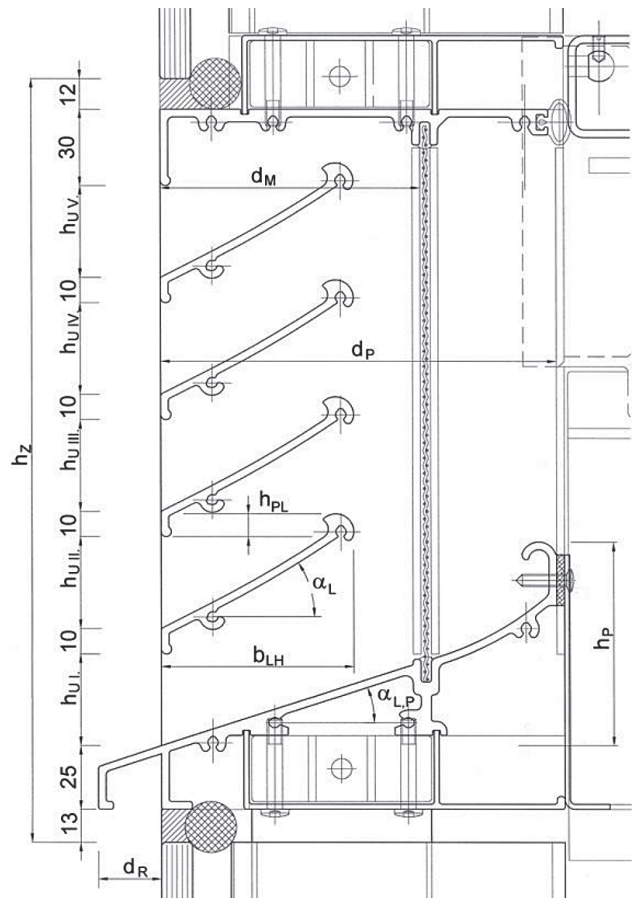

Figure 11. Scheme of the ventilation louvers for the quantification of their geometric-construction parameters 
Table 1 Dimensions of ventilation louvers (Figure 11)

\begin{tabular}{|c|c|c|c|c|c|c|}
\hline & & Variant 1 & Variant 2 & Variant 3 & Variant 4 & Variant 5 \\
\hline 1 & Elevation height of ventilation louvers $h_{\mathrm{z}}(\mathrm{mm})$ & 270 & 300 & 300 & 300 & 300 \\
\hline 2 & $\begin{array}{l}\text { Effective height of the ventilation louver } h_{\mathrm{U}}(\mathrm{mm}) \\
\text { Total free openings between blades along } \\
\text { the height of louvers }\end{array}$ & 156 & 180 & 165 & 180 & 176 \\
\hline 3 & Inclination of blades / threshold of louvers $\alpha_{\mathrm{L}, \mathrm{P}}\left({ }^{\circ}\right)$ & $15 / 15$ & $15 / 25$ & $25 / 25$ & $30 / 18$ & 30 \\
\hline 4 & $\begin{array}{l}\text { Width of a blade of the louvers } b_{\mathrm{LH}}(\mathrm{mm}) \text { in its } \\
\text { horizontal projection }\end{array}$ & 60 & 70 & 70 & 75 & 85 \\
\hline 5 & Height of the overlapping blades $h_{\mathrm{PL}}(\mathrm{mm})$ & -10 & 5 & 5 & 6 & 14 \\
\hline 6 & $\begin{array}{l}\text { Depth of threshold } d_{\mathrm{p}}(\mathrm{mm}) \\
\text { from facade plane }\end{array}$ & 160 & 148 & 148 & 155 & 154 \\
\hline 7 & Height of threshold $h_{\mathrm{P}}(\mathrm{mm})$ & 65 & 65 & 95 & 80 & 100 \\
\hline 8 & Depth of rain gutter $d_{\mathrm{R}}(\mathrm{mm})$ from facade plane & 25 & 25 & 25 & 0 & 0 \\
\hline 9 & $\begin{array}{l}\text { Location of grid } d_{\mathrm{M}}(\mathrm{mm}) \text { from facade plane of outer } \\
\text { glass curtain system }\end{array}$ & 110 & 105 & 105 & 102 & 102 \\
\hline 10 & $\begin{array}{l}\text { Grid dimension of the screen } \\
(\mathrm{mm}) \text {. Width } x \text { height }\end{array}$ & $11.5 \times 11.5$ & $11.5 \times 11.5$ & $\begin{array}{l}11.5 \times 11.5 \\
2 \times 2\end{array}$ & $\begin{array}{l}11.5 \times 11.5 \\
2 \times 2\end{array}$ & $2 \times 2$ \\
\hline
\end{tabular}

In this way, the splintering raindrops create a new rain element in the form of a drop of almost zero weight (similar to a drop when it is drizzling). These small rain elements are carried by the airflow, caused by strong wind exposure, deeply into the distribution channel on its floor plane and back plane throughout the whole width of the cavity. These extremely small water drops are, due to their very light weight, incapable of moving downwards through gravitational forces even on a smooth vertical plane, since the force of its surface tension is, in this case, stronger than the gravitational force:

$$
\mathrm{F}>\mathrm{G}
$$

$$
2 \cdot r_{z} \cdot \Delta \sigma>\rho \cdot g \cdot V
$$

where $r_{z}(m)$ is the radius of the area of a rain drop on a vertical plane; $\Delta \sigma(\mathrm{N} / \mathrm{m})$ is the adhesion constant of water, i.e. surface tension of water in contact with air; $\rho\left(\mathrm{kg} / \mathrm{m}^{3}\right)$ is the water density; $\mathrm{g}\left(\mathrm{m} / \mathrm{s}^{2}\right)$ is the gravitational acceleration; and $V\left(\mathrm{~m}^{3}\right)$ is the volume of a rain drop.

In cases when the examined building element was exposed for a longer period of time to the complex effects of wind-driven rain, static drops on the vertical back plane of the distribution channel increased their volume $V\left(\mathrm{~m}^{3}\right)$ and consequently their radius $r_{\mathrm{z}}(\mathrm{m})$. This phenomenon occurred until the balance of the forces of the surface tension and gravitation became equal, e.g., $\mathrm{F}=\mathrm{G}$.

Once the forces of the surface tension became smaller than the gravitational forces (eq. 5), the heavier drops started to move downwards on the vertical back plane of the distribution channel. In the parts of the investigated module where the function of the distribution channels is to exhaust air, the raindrops fell along the height of the cavity on the floor of the cavity one floor below.

The experiments of the hydrodynamic behaviour of the air intake openings of the five (5) variants of the ventilation louvers has led to the following observations and conclusions: the free horizontal slots between the blades of the ventilation louvers in Variants 1-3 (Figure 9) are not convenient from the point view of their hydrodynamic behaviour. The blades of the ventilation louvers must have an overlap of $h_{\mathrm{PL}}>0$. The inclination of the blades of ventilation louvers has a significant effect on their hydrodynamic behaviour and should be $\alpha_{\mathrm{L}}$ $\geq 30^{\circ}$. The width of the blades of the ventilation louvers has a significant effect on their hydrodynamic behaviour as well and should be more than $100 \mathrm{~mm}$.

The aerodynamic shape of the blades is recommended not only due to the overall aerodynamic resistance of the cavity, but also because of their function in terms of eliminating the splintering effect of raindrops. The inclination and height of the threshold blades of the ventilation louvers have a significant effect on the hydrodynamic properties as well, and the inclination angle of the threshold blade $\alpha_{\mathrm{L}, \mathrm{P}}$ should be more than $30^{\circ}$ (i.e., $\alpha_{L, P}>30^{\circ}$ ) with a height $h_{p} \geq 100 \mathrm{~mm}$ (Figure 11).

The experiments also confirmed that the elements of the ventilation louvers protruding from the plane of the outer skin of the double-skin facade in the form of a so-called cordon cornice drainage system, are also not suitable from the point of view of hydrodynamic behaviour. The structure of the protective screen of the ventilation louvers against birds and insects has a significant importance on their hydrodynamic behaviour in terms of a quantitative change in the water flow, which results in substantially lower values when a screen with a finer mesh is applied.

The optimal grid dimensions seem to be around $2 \times 2 \mathrm{~mm}$. The position of the screen against birds and insects in terms of its depth in the structure (which must always be placed behind the blades) does not have a significant effect on the hydrodynamic behaviour.

The open area at the top of the highest ventilation louver blade in variants 1 to 4 acts as a diffuser and causes the movement of the largest amount of water from the effects of the wind-driven rain. It is therefore more appropriate to avoid this solution, and it is much better to use the Variant 5. 

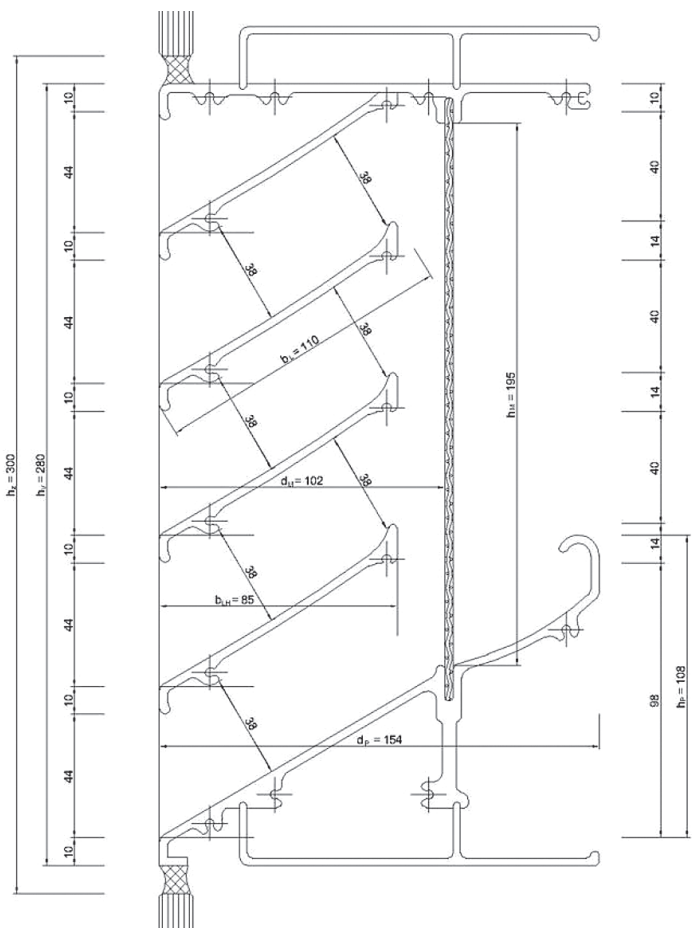

Figure 13. Design of the optimized variant of ventilation louvers No.5

Other observations from the measurements can be summarized as follows: Variants 1, 2 and 3 show the penetration of rainwater due to the complex effects of wind-driven rain at a speed of $v_{N} \leq 20 \mathrm{~m} / \mathrm{s}$ and at a difference in air pressure of $\Delta \mathrm{p}_{\mathrm{N}}=240 \mathrm{~Pa}$. For this reason, they are considered unsatisfactory in terms of the hydrodynamic behaviour of buildings. Variant 4 turned out to be one of the more convenient variants with the complex effects of wind-driven rain impacts at a speed of $\mathrm{v}_{\mathrm{N}} \leq 35 \mathrm{~m} / \mathrm{s}$, which corresponds to the difference in air pressure $\Delta \mathrm{p}_{\mathrm{N}}$ $=735 \mathrm{~Pa}$. The optimized solution for the ventilation louver was found in the shape of Variant 5 (Figure 13). This variant is suitable in the complex effects of wind-driven rain impacts at a speed of $\mathrm{v}_{\mathrm{N}} \leq 42 \mathrm{~m} / \mathrm{s}$ and at a steady difference in air pressure of $\Delta \mathrm{p}_{\mathrm{N}}=1058 \mathrm{~Pa}$.

Both Variants 4 and 5 can be considered as acceptable solutions for conditions in the Bratislava region (at the virtual boundary conditions of hydrodynamics) for buildings up to 20 floors.

\section{CONCLUSIONS}

It has been shown that the proper construction and shape of air inlets and outlets of air distribution channels significantly affects the quality of a naturally ventilated double-skin transparent façade. Even small details in the shape, position or inclination of louvres can significantly affect the functional aerodynamic and hydrodynamic behaviour of a corridor-shaped DSTF. The aerodynamic shape of blades is one of the fundamental conditions for their proper functioning when the constant movement of air through a cavity under every possible climatic condition is considered. The laboratory experiments performed in the rain chamber, which simulated the complex effects of wind-driven rain have shown that the geometry of louvers significantly contributes to their hydrodynamic behaviour, which is characterized by water impermeability.

Based on the knowledge gained from the results of the laboratory measurements, recommendations for the construction design of the air inlets and outlets have been drawn.

This article can help designers find solutions when deciding about this very challenging detail of a building facade, e.g., its air inlet properties.

However, the measurements have also confirmed the complexity of the whole problem and the large impact of small construction details on the hydrodynamic behaviour of a facade. It is therefore recommended that in each individual project design, the hydrodynamic properties of the distribution channels, including the air inlet and outlet, should be experimentally verified.

\section{Acknowledgement}

This work was supported by the Scientific Grant Agency of the Ministry of Education, Science, Research and Sport of the Slovak Republic and the Slovak Academy of Sciences in the project VEGA 1/0067/16 and by the Slovak Research and Development Agency under the contract No. APVV-16-0126. 


\section{REFERENCES}

Poirazis, H. (2006) Double skin facades, A Literature Review. Lund Institute of Technology, Lund, Sweeden.

Bielek, B. - Bielek, M. - Palko, M. (2002) Double-skin transparent facades of buildings. $1^{\text {st }}$ volume : History, development, classification and theory of design. Bratislava: Coreal.

Vaglio, J. - Patterson, M. - Hooper, S. (2010) Emerging Applications and Trends of Double-Skin Facades, In proceedings of International Conference on Building Envelope Systems and Technologies (ICBEST) 2010 in Vancouver, Canada.

Directive 2010/31/EU of the European Parliament and of the Council of 19 May 2010 on the energy performance of buildings, Official J Eur Union (2010).

COST Action TU1403, Adaptive Facades Network

COST Action TU1303, Novel structural skins: Improving sustainability and efficiency through new structural textile materials and designs.

Bielek, B. - Bielek, M. - Kusý, M. - Paňák, P. (2002) Double-skin transparent facades of buildings. $2^{\text {nd }}$ volume : development, simulation, experiment and design of the facade of the Slovak National Bank building in Bratislava. Bratislava: Coreal.

Todorovic, B. - Maric, B. (1998) The influence of double façades on building heat losses and cooling loads. Faculty of Mechanical Engineering, Belgrade University, Belgrade, Yugoslavia.

Arons, D. (2000) Properties and Applications of Double-Skin Building Facades, MSc thesis in Building Technology, Massachusetts Institute of Technology (MIT), USA.

Gan, G. (2001) Thermal transmittance of multiple glazing: computational fluid dynamics prediction. Applied Thermal Engineering 21, 1583-1592.

Saelens, D. - Hens, H. (2001) Experimental evaluation of airflow in naturally ventilated active envelopes, Journal of Building Physics 25 (2), 101-127.

Hensen, J.L.M. - Bartak, M. - Drkal, F. (2002) Modeling and simulation of double-skin facade systems. ASHRAE Transactions, vol. 108:2, American Society of Heating, Refrigerating, and Air-Conditioning, Engineers, Atlanta, GA.

Saelens, D. (2002) Energy Performance Assessments of Single Storey Multiple-Skin Facades. $\mathrm{PhD}$ thesis, Laboratory for Building Physics, Department of Civil Engineering, KU Leuven, Belgium.

Gratia, E. - Herde, A.D. (2004) Natural ventilation in a double-skin facade. Energy and Buildings 36(2): 137-146.

Gratia, E. - Herde, A.D. (2004) Is day natural ventilation still possible in office buildings with a double-skin facade? Building and Environment, 39(4), 399-409.

Grabe, J.V. (2002) A prediction tool for the temperature field of double facades. Energy and Buildings 34, 891-899.

Manz, H. (2002) Numerical simulation of heat transfer by natural convection in cavities of facade elements. Energy and Buildings 35 (2003), 305-311.
Mingotti, N. - Chenvidyakarn, T. - Woods, A.W. (2011) The fluid mechanics of the natural ventilation of a narrow-cavity double-skin façade. Building and Environment 46(7), 1523-1523.

Nore, K. - Blocken, B. - Thue, J.V. (2010) On CFD simulation of wind-induced airflow in narrow ventilated facade cavities: Coupled and decoupled simulations and modelling limitations. Building and Environment 45(8), 1834-1846.

Blanco, J. M. - Arriaga, P. - Rojí, E. - Cuadrado, J. (2014) Investigating the thermal behavior of double-skin perforated sheet façades: Part A: Model characterization and validation procedure. Building and Environment 82, 50-62.

Parra, J. - Guardo, A. - Egusquiza, E. - Alavedra, P. (2015) Thermal Performance of Ventilated Double Skin Façades with Venetian Blinds, Energies 8, 4882-4898; doi:10.3390/en8064882

Gratia, E. - de Herde, A. (2007) The most efficient position of shading devices in a double-skin façade. Energy and Buildings 39, 364-373.

Manz, H. - Simmler, H. (2003) Experimental and numerical study of a mechanically ventilated glass double façade with integrated shading device. Proceedings of the Building Physics Conference, Leuven.

Poirazis, H. - Rosenfeld, J.L.J. (2003) Modelling of Double Skin Façades - Results obtained using WIS, Technical University of Denmark, (DTU) Sagsrapport SR-03-08, ISSN 1601-8605.

Gratia, E. - de Herde, A. (2004) Optimal operation of a south double-skin façade. Energy and Buildings 36, 41-60.

Baldinelli, G. (2009) Double skin façades for warm climate regions: Analysis of a solution with an integrated movable shedding system. Building and Environment 44, 1107-1118.

Guardo, A. - Coussirat, M. - Egusquiza, E. - Alavedra, P. - Castilla, R. (2009) $A C F D$ approach to evaluate the influence of construction and operation parameters on the performance of active transparent façades in Mediterranean climates. Energy and Buildings 41, 534-542.

Zeng, Z. - Li, X. - Zhu, Y. (2012) Modeling ventilation in naturally ventilated double-skin façade with a venetian blind. Building and Environment 57(1).

Tzempelikos, A. (2008) The impact of Venetian blind geometry and tilt angle on view, direct light transmission and interior illuminance. Solar Energy 82, 1172-1191.

Manz, H. - Menti, U. (2012) Energy performance of glazings in European climates. Renewable energy 37, 226-232.

Manz, H. - Schaelin, A. - Simmler, H. (2004) Airflow patterns and thermal behavior of mechanically ventilated glass double façades. Building and Environment 39, 1023-1033.

Saelens, D. - Blocken, B. - Roels, S. - Hens, H. (2005) Optimization of the energy performance of multiple-skin facades. Ninth International IBPSA Conference. Montreal, Canada, 1059-1066.

Ding, W. - Hasemi, Y. - Yamada, T. (2005) Natural ventilation performance of a double-skin façade with a solar chimney. Energy and Buildings 37(4), 411-418. 
Cole, J.R. - Connery, K. - Rousseau, D. - Theaker, I. (1998) Chapter SF5, Shape the building to induce buoyancy airflow into \& out of interior spaces, Green building design \& construction guidelines. City of Santa Monica Project Advisory Committee

Saelens, D. - Roels, S. - Hens H. (2003) On the influence of the inlet temperature in multiple-skin facade modelling, Eighth International IBPSA Conference, Eindhoven, The Netherlands.

Gelesz, A. - Reith, A. (2011) Classification and re-evaluation of double skin facades. The $17^{\text {th }}$ Building Services, Mechanical and Building Industry Days, Urban Energy Conference, Debrecen, Hungary. 65-72.

Chow, W.K. - Hung, W.Y. - Gao, Y. - Zou, G. - Dong, H. (2007) Experimental Study on Smoke Movement Leading to Glass Damages in Double-skinned Façade, Construction and Building Materials, 21(3), 556-566.

Chow, C.L. - Gao, Y. - Dong, H. (2012) Selected Experimental Data Compiled from Full-scale Burning Tests on Glass Double-skin Façade Systems. International Journal on Engineering Performance-based Fire Codes

Ni. Z. - Lu. S. - Peng, L. (2012) Experimental studies on fire performance of double-skin glass facades. Journal of Fire Science $30(5), 457-472$

Chow, W.K. - Hung, W.Y. (2006) Effect of cavity depth on smoke spreading of double-skin façade. Building and Environment 200641 (7), 970-979

Hongisto, V. (2006) Sound Insulation of Double Panels - Comparison of Existing Prediction Models. Acta Acustica United with Acustica 92, 61-78.

Roozen, B. - Muellner, H. - Labelle, L. - Rychtarikova, M. - Glorieux, C. (2015) Influence of panel fastening on the acoustic performance of light-weight building elements: study by sound transmission and laser scanning vibrometry. Journal of Sound and Vibration 346, 100-116
Muellner, H. - Freyb, A. - Humera, C. (2008) Sound insulation properties of building elements, considering the frequency range below $100 \mathrm{~Hz}$. In proceedings of Euronoise Paris 2008.

Dijckmans, A. - Vermeir, G. (2013) Numerical investigation of the repeatability and reproducibility of laboratory sound insulation measurements. Acta Acustica united with Acustica 99, 421-432.

Blasco, M. - Crispin, Ch. (2004) Geventileerde Dubbele Gevels Akoestische Evaluatie In situ en labo metingen, modelisatie en evaluatie van de toepasbaarheid van de bestaande normalisatie. WTCB

Blasco, M. (2012) Top of Form

An acoustic approach to double facades: A general overview and sound insulation prediction model, Dissertaion thesis.

Urbán, D. - Zat'ko, P. - Dlhý, D. - Tomašovič, P. - Roozen, N.B. Rychtarikova, M. - Glorieux, C. (2014) Standing Waves in the Cavity of Double Transparent Facades, In proceedings of Forum Acusticum 2014 Cracow, Poland.

Urbán, D. - Roozen N.B. - Tomašovič, P. - Rychtáriková M. Zat'ko, P. - Glorieux, C. (2016) Assessment of sound insulation of naturally ventilated double skin facades, Building and Environment 110, 148-160. (DOI: 10.1016/j.buildenv.2016.10.004)

Bestfacade (2007) WP 5 Report Best Practice Guidelines, Best Practice for Double Skin Facades, Blomsterberg, A (ed.), Intelligent Energy Europe.

Palko, M. (2015) Aerodynamic characteristics of a double skin façade, 20th SVSFEM ANSYS Users' Group Meeting and Conference 2012, Přerov, Czech Rep. 